\title{
Gadd45 $\beta$ silencing impaired viability and metastatic phenotypes in cholangiocarcinoma cells by modulating the EMT pathway
}

\author{
KYAW ZWAR MYINT ${ }^{1}$, PORNPARN KONGPRACHA ${ }^{1}$, PANTHIP RATTANASINGANCHAN ${ }^{2}$, \\ KAWIN LEELAWAT ${ }^{3}$, PENPAK MOOLTHIYA ${ }^{2}$, KITTIPONG CHAIYABUTR ${ }^{3}$ and RUTAIWAN TOHTONG ${ }^{1}$ \\ ${ }^{1}$ Department of Biochemistry, Faculty of Science, Mahidol University; ${ }^{2}$ Department of \\ Clinical Chemistry, Faculty of Medical Technology, Huachiew Chalermprakiet University; \\ ${ }^{3}$ Department of Surgery, Rajavithi Hospital, Bangkok 10400, Thailand
}

Received January 5, 2017; Accepted November 10, 2017

DOI: $10.3892 / 01.2017 .7706$

\begin{abstract}
Growth arrest and DNA damage-inducible- $\beta$ $($ Gadd $45 \beta)$ is a stress-response protein involved in a number of processes, including cell cycle control, DNA repair, survival and death control, and stress signaling, depending on its interactions. Gadd $45 \beta$ expression is dysregulated in numerous types of cancer, functioning as either a tumor promoter or a tumor suppressor. However, the functions of Gadd $45 \beta$ in cholangiocarcinoma (CCA), particularly in metastasis, has not been studied. The immunohistochemical analysis of Gadd $45 \beta$ expression revealed that $75 \%$ of histological specimens from patients with CCA expressed high levels of Gadd $45 \beta$, and that high Gadd $45 \beta$ expression was associated with metastasis. The role of Gadd $45 \beta$ in CCA was examined using siRNA-mediated gene knockdown in HuCCA-1, a human CCA cell line established from a Thai patient. The effects of Gadd $45 \beta$ downregulation upon cell viability and death, invasion, migration, matrix metalloproteinase (MMP) activity and epithelial-mesenchymal transition (EMT) marker expression were investigated. Gadd $45 \beta$ knockdown impaired cell viability, which was associated with the induction of apoptosis. In addition, there was a marked reduction in invasion and migration, although MMP activity was unaffected. Impairment of these metastatic properties was accompanied by the decreased expression of EMT markers, including Slug, vimentin, claudin-1 and zona occludens protein 1 , whereas E-cadherin expression was increased. The present study
\end{abstract}

Correspondence to: Dr Rutaiwan Tohtong, Department of Biochemistry, Faculty of Science, Mahidol University, 6 Rama Road, Rajthevi, Bangkok 10400, Thailand

E-mail: rutaiwan.toh@mahidol.ac.th

Abbreviations: CCA, cholangiocarcinoma; ZO-1, zona occludens protein 1; MMP, matrix metalloproteinase; EMT, epithelialmesenchymal transition; siRNA, small interfering RNA

Key words: Gadd $45 \beta$, cholangiocarcinoma, apoptosis, epithelialmesenchymal transition, metastasis suggests that Gadd $45 \beta$ is involved in regulating the viability and the metastatic potential of CCA cells, which may be mediated by the modulation of the EMT pathway.

\section{Introduction}

Cholangiocarcinoma (CCA) is a cancer of the bile duct caused by the malignant transformation of cholangiocytes, the epithelial cells lining the bile duct. CCA is the second most common type of primary hepatic malignancy $(1,2)$. Due to late diagnosis, resistance to chemo- and radiotherapy, and the high rates of local invasion and distant metastasis, the prognosis for CCA is very poor. The median survival time of patients with CCA is $<2$ years (3), and the 5-year survival rate of patients receiving curative resection is $0-40 \%$ (4). The prevalence of CCA is the highest in Asia, particularly in the northeastern region of Thailand (5). Opisthorchis viverrini infection is hypothesized to be a causal factor of CCA in Thailand, as it is markedly associated with the incidence of CCA (6).

In total, $>90 \%$ of cancer-associated mortality is due to the local or distant metastasis of cancer cells (7). The epithelial-mesenchymal transition (EMT) is an important process in cancer metastasis, characterized by alterations in the gene expression and morphology of cells, which leads to a reduction of intercellular adhesion, and an increase in cell motility (8-11). This process is associated with a reduction of E-cadherin expression $(12,13)$ and an increase in the expression of vimentin, an intermediate filament protein, leading to increased cell motility and promoting tumor metastasis $(14,15)$.

Growth arrest and DNA damage-inducible- $\beta$ (Gadd45 $\beta$ ) is a stress-response protein; its expression is induced by physiological or environmental stress. The aberrant expression of Gadd $45 \beta$ in various types of cancer has implicated its involvement in tumorigenesis (16). Gadd $45 \beta$ belongs to the Gadd45 protein family (Gadd $45 \alpha$, Gadd $45 \beta$, Gadd $45 \gamma$ ) (17). Gadd $45 \beta$ may form a homodimer or heterodimer with the other Gadd45 proteins, or interact with a variety of other proteins, including proliferating cell nuclear antigen, cyclin-dependent kinase 1, p21, mitogen-activated protein kinase kinase kinase 4, mitogen-activated protein kinase kinase 7 and p38 mitogen activated protein kinase (MAPK). The function of Gadd45 $\beta$ differs depending on the interacting molecules, including cell 
cycle control, DNA repair, survival and death control, and stress signaling (18-22).

Cancer cells must survive and propagate in a strenuous environment of hypoxia, nutrient competition and oxidative stress (23). It is essential for cells to acquire the ability to thrive in these stressful conditions. The function of Gadd $45 \beta$ as a stress-response protein in cancer is paradoxical; the downregulation of Gadd $45 \beta$ via promoter methylation in hepatocellular carcinoma suggests that Gadd $45 \beta$ may act as a tumor suppressor (24), whereas the upregulation of Gadd $45 \beta$ in colorectal cancer was associated with recurrence and mortality of patients with colorectal cancer (25), suggesting a tumor-promoting role. When the Gadd $45 \beta$ gene from normal adjacent tissue was over-expressed in colorectal cancer cell lines, apoptotic cell death was induced (25). In addition, Gadd $45 \beta$ was identified as upregulated in the metastasis of uveal melanoma to the liver (26), and the silencing of Gadd $45 \beta$ in human embryonic carcinoma cells decreased viability and invasiveness (27), suggesting that Gadd $45 \beta$ may contribute to the malignant phenotypes of cancer. However, the function of Gadd $45 \beta$ in metastasis and EMT is not yet fully characterized.

In the present study, it was identified that patients with CCA exhibit increased Gadd $45 \beta$ expression in tumor tissue, and that a high level of Gadd $45 \beta$ expression was associated with metastasis. Gadd $45 \beta$ expression in a CCA cell line, HuCCA-1, was suppressed using siRNA-mediated gene silencing, and the effects on cell viability, survival and death signaling pathways, migration, invasiveness, and the EMT pathway were studied. The data of the present study thus indicated that Gadd $45 \beta$ expression promoted the viability, migration and invasion of the HuCCA-1 cells, traits required for successful metastasis.

\section{Materials and methods}

Ethical approval. All procedures performed in the present study involving human participants were performed in accordance with the 1964 Declaration of Helsinki and its later amendments, or comparable ethical standards. The study was conducted with the approval of the Ethical Committee of Rajavithi Hospital (Bangkok, Thailand).

Immunohistochemical (IHC) staining. Paraffinized tissue samples from 28 patients with CCA who had undergone surgical treatment at Rajavithi Hospital between January 2010 and October 2010 were selected for retrospective analysis. Standard IHC technique was used for the detection of Gadd $45 \beta$ in paraffinized sections on glass slides. Polyclonal Gadd $45 \beta$ antibody (HPA029816-100UL; 1:500 dilution; Sigma-Aldrich; Merck KGaA, Darmstadt, Germany) was hybridized with the sections overnight at $4^{\circ} \mathrm{C}$, followed by incubation with biotinylated goat anti-rabbit IgG at RT for $1 \mathrm{~h}$ (E0432; dilution 1:500; Dako; Agilent Technologies, Inc., Santa Clara, CA, USA). Subsequently avidin-biotin-peroxidase conjugate was added (ABC Elite; Vector Laboratories, Burlingame, CA, USA) for $30 \mathrm{~min}$ at room temperature and the immunohistochemical reaction was developed with freshly prepared reagents from a Histofine SAB-PO kit (Nichirei, Inc., Tokyo, Japan). The samples were visualized at $\mathrm{x} 400$ magnification using an Olympus BX53 microscope (Olympus Corporation, Tokyo, Japan) and categorized into four grades according to the intensity and percentage of positively stained cells: Negative or $<5 \%$, grade 0 ; weak or $5-25 \%$, grade 1 ; moderate or $25-50 \%$, grade 2 ; and strong or $>50 \%$, grade 3 . IHC grade 0 (3 cases) and grade 1 (4 cases), which exhibited weak and/or $<25 \%$ staining, were grouped as low expression, whereas grade 2 (5 cases) and grade 3 (16 cases), which exhibited moderate to strong and/or $>25 \%$ staining, were grouped as high expression of Gadd $45 \beta$ for the purpose of statistical analysis.

Cell line and culture condition. The human CCA cell line, HuCCA-1 (28), developed from a Thai patient with CCA, was used for the study. The cells were provided by Professor Satitaya Sirisinha (Mahidol University, Bangkok, Thailand). These cells were grown in HAM's F-12 medium supplemented with $10 \%$ fetal bovine serum (Gibco; Thermo Fisher Scientific, Inc., Waltham, MA, USA) at $37^{\circ} \mathrm{C}$ in $5 \% \mathrm{CO}_{2}$ humidified atmosphere.

Small interfering (si)RNA-mediated Gadd45 $\beta$ gene silencing. Commercial Gadd $45 \beta$ siRNA [GADD $45 \beta$ siRNA(h): sc-37416], a pool of 3 different siRNA duplexes to the Gadd $45 \beta$ gene (NCBI RefSeq. 12759252), was purchased from Santa Cruz Biotechnology, Inc. (Dallas, TX, USA). Silencer ${ }^{\circledR}$ Negative control siRNA no. 1 (cat. no. 4404021; Ambion; Thermo Fisher Scientific, Inc.) was used as negative control siRNA. The cells were washed with PBS and detached using $0.25 \%$ Trypsin/EDTA (Gibco; Thermo Fisher Scientific, Inc.). Cells were seeded at $2 \times 10^{5}$ cells/well into a 6 well plate for $24 \mathrm{~h}$, then transfected with $40 \mathrm{nM}$ siRNA using Lipofectamine ${ }^{\circledR}$ RNAiMax reagent (Invitrogen; Thermo Fisher Scientific, Inc.) according to the manufacturer's instructions. The medium containing transfection reagents was changed for $10 \%$ FBS supplemented HAM's-F12 at $24 \mathrm{~h}$ after transfection.

Western blot analysis. At $48 \mathrm{~h}$ post-transfection, total cellular protein was extracted and prepared following a protocol described previously (29). Each protein sample of $40 \mu \mathrm{g}$ was separated via SDS-PAGE (12\% gel; $120 \mathrm{~V}$ for $2 \mathrm{~h}$ ) followed by an electroblotting transfer of the protein to a nitrocellulose membrane at $30 \mathrm{~V}$ at $4^{\circ} \mathrm{C}$ for $15 \mathrm{~h}$. The membranes were blocked in $1.5 \%$ skimmed milk at room temperature for $1 \mathrm{~h}$, the membranes were incubated with the primary antibodies at $4^{\circ} \mathrm{C}$ overnight on a rocking platform. The next day, the membranes were washed with TBS with Tween-20 prior to incubation with horseradish peroxidase-conjugated secondary antibodies for $1 \mathrm{~h}$ at room temperature. Following 3 washes with TBST for 10 min, ECL Plus Western Blotting Detection system (Bio-Rad Laboratories, Inc., Hercules, CA, USA) was used to visualize the immunoreactive bands in G:Box ChemiXL 1.4 (Syngene; Synoptics, Cambridge, UK).

Rabbit polyclonal Gadd45 $\beta$ antibodies were purchased from Abcam (Cambridge, UK) and goat polyclonal GAPDH antibodies from Santa Cruz Biotechnology, Inc. The rest of the antibodies used in the study were purchased from Cell Signaling Technology, Inc. (Danvers, MA, USA); the details regarding all antibodies used in western blotting are included in Table I. Densitometry analysis was performed using ImageJ software (version $1.49 \mathrm{v}$; National Institutes of Health, Bethesda, MD, USA) (30). The density of the protein of interest relative to GAPDH was determined in HuCCA-1 cells 


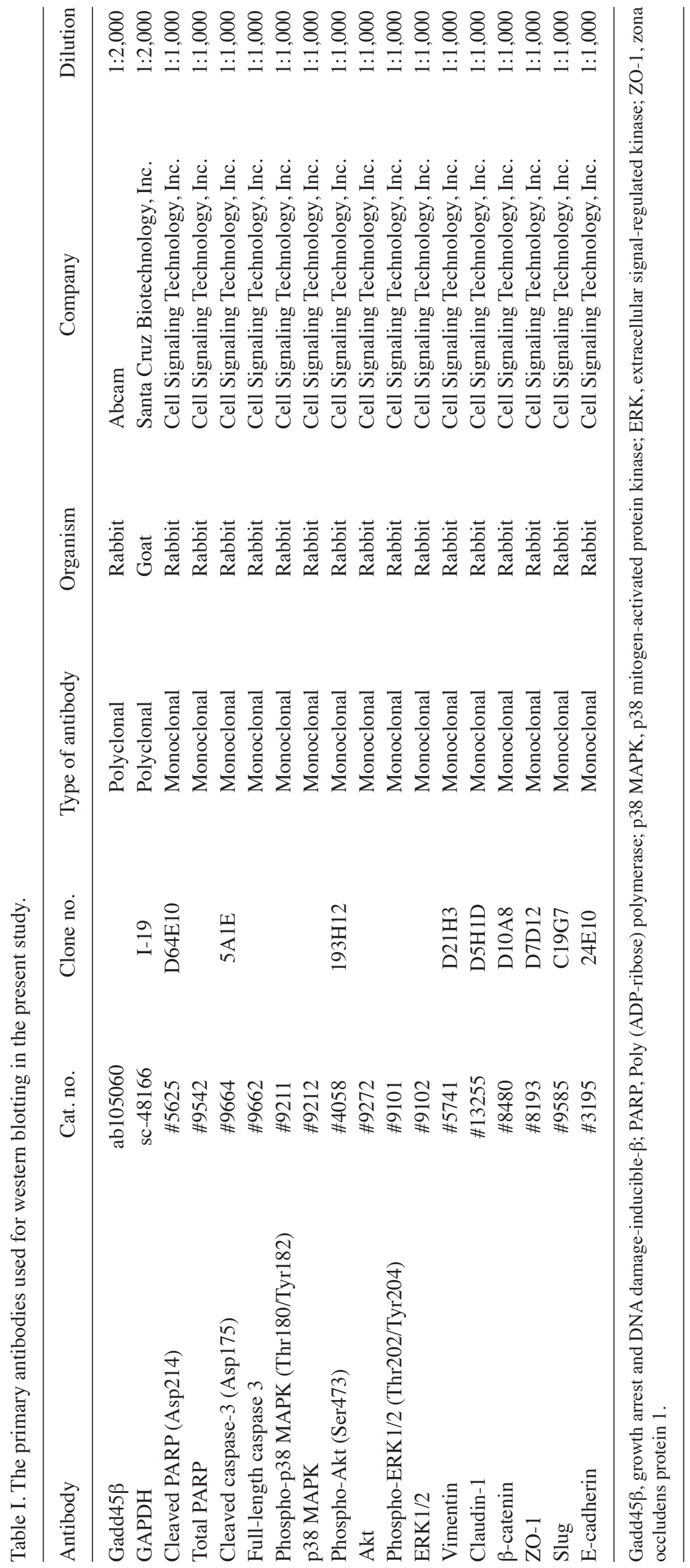


transfected with Gadd $45 \beta$ or negative control siRNA. The activation of Akt, p38 MAPK and extracellular signal-regulated kinase (ERK) $1 / 2$ signaling pathways was examined using phospho-specific antibodies at $48 \mathrm{~h}$ after siRNA transfection. The densitometry measurements for total Akt, ERK1/2 and p38 MAPK were used for the normalization of protein loading. The phospho-protein/total protein density ratio was determined in HuCCA-1 cells transfected with Gadd $45 \beta$ siRNA or negative control siRNA. The phospho-protein/total protein density ratio of cells transfected with negative control siRNA was designated as $100 \%$.

\section{Cell viability assays}

Live/Dead ${ }^{\circledast}$ cell viability assay. HuCCA-1 cells were grown on coverslips prior to transfection with siRNA. At $48 \mathrm{~h}$ post-transfection, cell viability was assessed using the Live/Dead ${ }^{\circledR}$ Viability/Cytotoxicity kit for mammalian cells (Invitrogen; Thermo Fisher Scientific, Inc.) according to the manufacturer's instructions. Briefly, a working solution, containing $2 \mu \mathrm{M}$ calcein AM and $4 \mu \mathrm{M}$ ethidium homodimer (EthD-1), was prepared in PBS. The cells were washed with pre-warmed PBS, and $150 \mu 1$ of Live/Dead solution was applied to each cover slip. Following incubation at $37^{\circ} \mathrm{C}$ in a $5 \% \mathrm{CO}_{2}$ humidified atmosphere for $30 \mathrm{~min}$, the reagents were removed and the cover slips were washed with PBS, mounted on the glass-slides, and viewed using a Nikon Eclipse TE2000-U microscope (Nikon Corporation, Tokyo, Japan) using B-2A (green, calcein) and G-2A (red, EthD-1) excitation filters. Images were recorded at x100 total magnification using ACT-1C software (version 1.02; Nikon Corporation). Live cells were stained with calcein-AM (green), whereas dead cells were stained with ethidium homodimer (red).

WST-1 assay. A total of 5,000 HuCCA-1 cells were seeded in 96-well plates for $24 \mathrm{~h}$ prior to siRNA transfection. At 24, 48 and $72 \mathrm{~h}$ post-transfection, $10 \mu \mathrm{l}$ of WST-1 reagent (Roche Diagnostics, Basel, Switzerland) was added into each well. The plates were incubated at $37^{\circ} \mathrm{C}$ in a humidified atmosphere containing $5 \% \mathrm{CO}_{2}$ for $2 \mathrm{~h}$. Then the absorbance at $450 \mathrm{~nm}$ was measured.

Hoechst staining. At $48 \mathrm{~h}$ post-transfection, the culture media was carefully removed to avoid the loss of detached cells. HuCCA- 1 cells were then fixed in $2 \%$ w/v paraformaldehyde solution for $30 \mathrm{~min}$ at room temperature prior to permeabilization using $0.03 \% \mathrm{v} / \mathrm{v}$ Triton X-100 for $30 \mathrm{~min}$. Nuclear staining was performed with Hoechst 333258 dye at room temperature $(5 \mu \mathrm{g} / \mathrm{ml}$; Thermo Fisher Scientific, Inc.) for $2 \mathrm{~h}$, followed by visualization at $\mathrm{x} 400$ total magnification with an Olympus IX83 live cell fluorescence microscope (Olympus Corporation).

Gelatin zymography. To analyze the activity of MMPs, the gelatinase activity of the enzymes secreted into the medium was determined using gelatin zymography assay, following a previously described protocol (29). The gelatinolytic activity of MMPs was observed as clear bands on the blue background of the Coomassie-stained gel. Densitometry analysis was performed using ImageJ software (30).
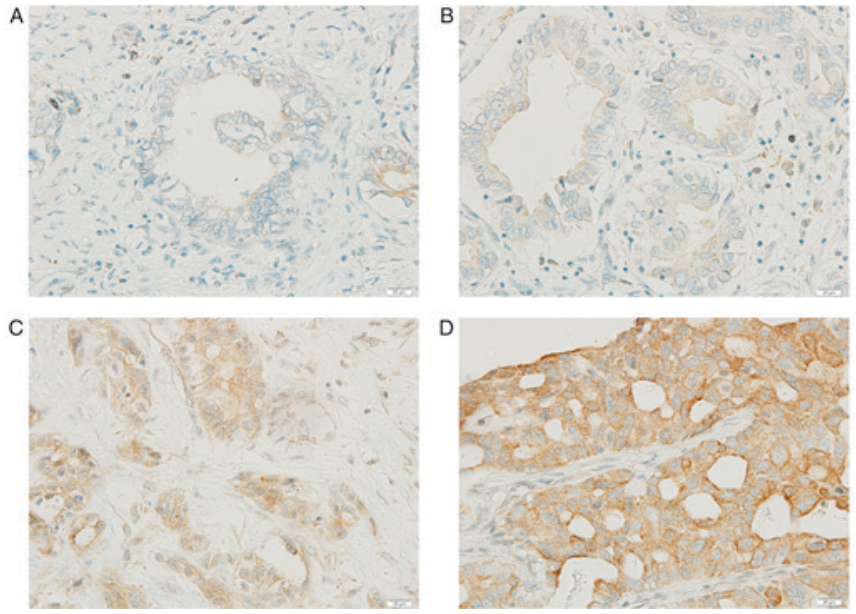

Figure 1. Gadd45 $\beta$ expression in CCA tissues, as determined by IHC Paraffinized CCA tissue sections from patients were stained with a polyclonal anti-Gadd $45 \beta$ antibody. A total of $21 / 28$ patients (75\%) exhibited the high levels of Gadd $45 \beta$ expression. Representative images of IHC (A) grade 0 and (B) grade 1+, which were designated as low expression, and (C) grade $2+$ and (D) grade 3+; which were designated as high expression, are presented. Gadd $45 \beta$, growth arrest and DNA damage-inducible- $\beta$; CCA, cholangiocarcinoma; IHC, immunohistochemistry.

Cell invasion and migration assays. Cells were harvested at $48 \mathrm{~h}$ post-transfection for in vitro invasion and migration assays using transwell chambers, as described by Li et al (31). Briefly, HuCCA-1 cells $\left(1 \times 10^{5}\right.$ cells/well) transfected with Gadd $45 \beta$ siRNA or negative control siRNA were seeded into the upper chamber of the transwells coated with Matrigel for the invasion assay and with no coating for the migration assay, and analyzed after $6 \mathrm{~h}$ of incubation at $37^{\circ} \mathrm{C}$. HAM's F-12 supplemented with $10 \%$ FBS, used as chemoattractant, was added to the lower chamber. Cells were seeded in the upper chamber in serum free medium. Three independent experiments were performed in duplicate transwells.

Statistical analysis. Data is presented as the mean \pm standard deviation and every experiment was performed at least three times. The $\chi^{2}$ test was used for clinicopathological data analysis, and experimental data analysis was performed using a paired $t$-test. $\mathrm{P}<0.05$ was considered to indicate a statistically significant difference.

\section{Results}

High levels of Gadd45 $\beta$ expression are associated with metastatic incidence in $C C A$. Gadd $45 \beta$ expression in the histological specimens of CCA tissue from 28 patients was examined with IHC staining. The expression of Gadd $45 \beta$ was detected in all tumor tissues $(n=28)$, and $75 \%(n=21)$ exhibited higher Gadd $45 \beta$ expression than the surrounding stroma (Fig. 1A-D). Although Gadd $45 \beta$ expression was previously reported to be moderate in the liver, gall bladder and pancreas (32), the expression level in cholangiocytes or CCA tissue has not previously been reported, to the best of our knowledge. A high level of Gadd45 $\beta$ expression was associated with the incidence of metastasis in patients $(\mathrm{P}=0.035)$, although no statistically significant association was observed 

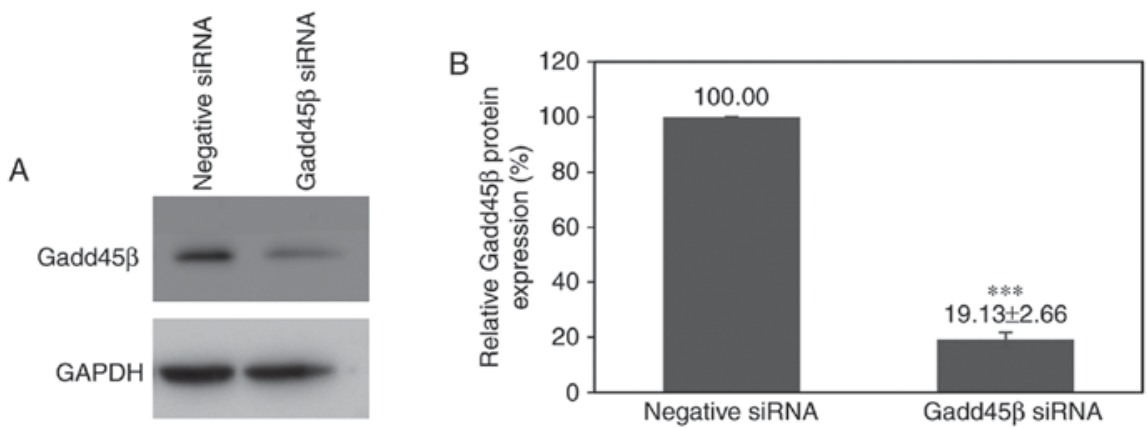

Figure 2. siRNA-mediated gene silencing efficiency in HuCCA-1 cells. (A) Representative images of the western blot analysis of Gadd45 $\beta$ silencing in HuCCA-1. (B) Densitometry analysis of the efficiency of Gadd $45 \beta$ silencing, using GAPDH as an internal control. Columns, mean of three independent experiments; bars, standard deviation. ${ }^{* * *} \mathrm{P}=0.0004$ compared with negative control siRNA transfection. siRNA, small interfering RNA; Gadd45 $\beta$, growth arrest and DNA damage-inducible- $\beta$.
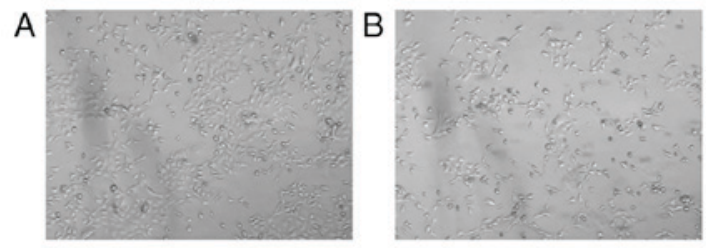

E
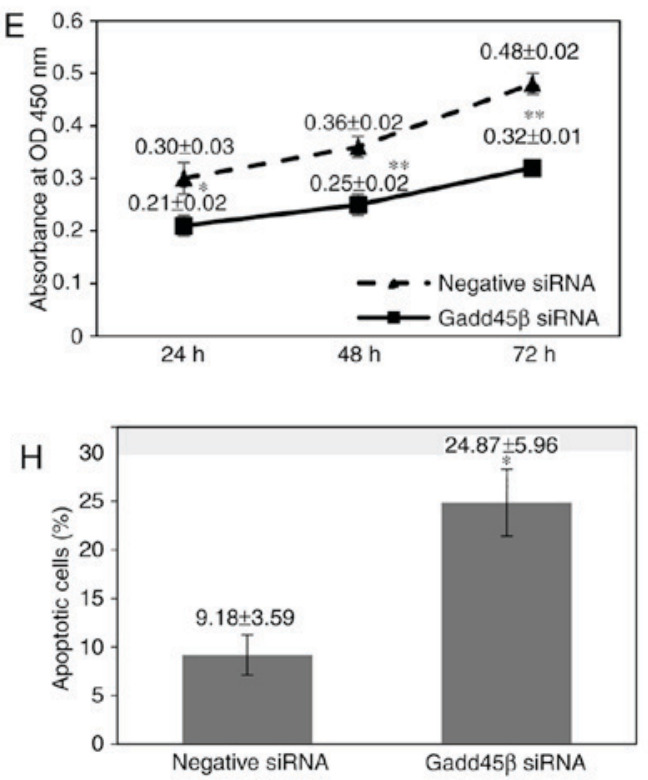
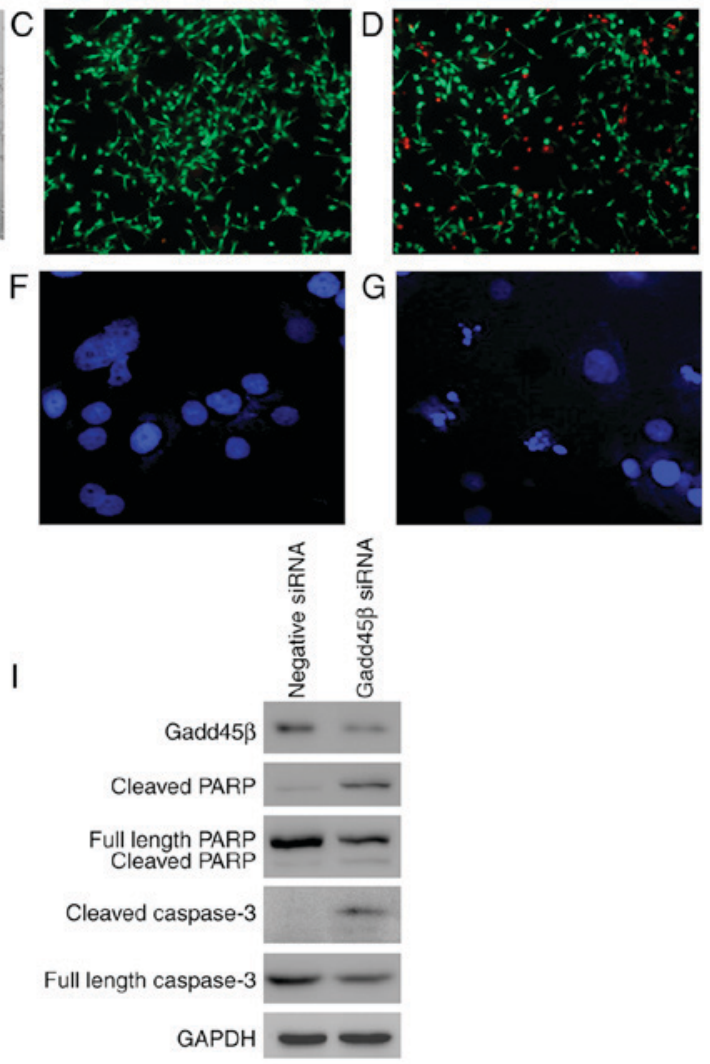

Figure 3. Gadd45 $\beta$ silencing impaired proliferation and induced apoptosis in HuCCA-1 cells. Light microscopic images of (A) negative control siRNA and (B) Gadd45 $\beta$ siRNA transfected HuCCA-1 cells at $48 \mathrm{~h}$ (x40 magnification). An evident decrease in the confluence of the Gadd45 $\beta$ siRNA transfected cells was noted, compared with negative control siRNA-transfected cells. In a Live/Dead Viability Assay, (C) negative control HuCCA-1 cells were relatively less likely to be dead (red) compared with (D) Gadd45 $\beta$-silenced cells (x40 magnification). (E) WST-1 proliferation assay. Gadd $45 \beta$ siRNA transfection induced a significant reduction in HuCCA-1 cell proliferation. Data points, mean of three independent experiments; bars, standard deviation. ${ }^{*} \mathrm{P}<0.05$; ${ }^{* * *} \mathrm{P}<0.005$ compared with negative control siRNA transfection. Hoechst 333258 staining of HuCCA-1 cells transfected with (F) negative control siRNA and (G) Gadd45 $\beta$ siRNA (x400 magnification). The nuclei of live cells were homogenously stained in blue, whereas those of apoptotic cells appeared condensed and fragmented. (H) Percentage of apoptotic cells in HuCCA-1 cells following Gadd $45 \beta$ silencing for $48 \mathrm{~h}$. Columns, mean of three independent experiments; bars, standard deviation; "P<0.05. (I) Representative images of the western blot analysis of caspase-3 activation and cleavage of PARP in HuCCA- 1 following Gadd45 $\beta$ silencing for $48 \mathrm{~h}$. Gadd $45 \beta$, growth arrest and DNA damage-inducible- $\beta$; siRNA, small interfering RNA.

between the level of Gadd45 $\beta$ expression and age, sex, lymph node involvement or differentiation status (Table I).

Gadd $45 \beta$ knockdown reduces the viability of $\mathrm{HuCCA}-1$ cells. To investigate the functional importance of Gadd $45 \beta$ in CCA, Gadd $45 \beta$ expression was suppressed using siRNA-mediated silencing in HuCCA-1, a CCA cell line that expresses moderate levels of Gadd $45 \beta$. Gadd $45 \beta$ siRNA transfection decreased the expression of Gadd45 $\beta$ in HuCCA-1 to $19.13 \pm 2.66 \%$ relative to negative control siRNA transfection (Fig. 2A and B).

During Gadd45 $\beta$ silencing experiments, a decrease in the confluence of Gadd $45 \beta$-silenced HuCCA- 1 cells was observed compared with negative control siRNA-transfected cells (Fig. 3A and B). Furthermore, there was an 
increase in the number of cells floating in the medium of Gadd $45 \beta$-silenced HuCCA-1 cells, indicating that silencing of Gadd $45 \beta$ perturbed the viability of HuCCA-1 cells (data not shown). A Live/Dead ${ }^{\circledR}$ cell viability assay confirmed that there was an increase in the number of dead cells in HuCCA-1 cells when Gadd $45 \beta$ was silenced (Fig. 3 C and D). Cell viability was assessed using a WST-1 assay, in which the WST-1 reagent was added directly into the cells without removing the culture medium, preventing the loss of detached viable cells. Consistent with visual observation, Gadd $45 \beta$ silencing significantly decreased the viability of HuCCA-1 cells (Fig. 3E).

Gadd $45 \beta$ silencing kills HuCCA-1 cells via apoptosis. The mode of cell death in HuCCA-1 cells upon Gadd $45 \beta$ silencing was examined by staining the nuclear DNA with Hoechst 333258. Upon silencing of Gadd $45 \beta$, HuCCA- 1 cells were observed to exhibit nuclear condensation and DNA fragmentation, characteristics of apoptotic cells (33). The nuclei of live cells were homogenously stained in blue, whereas those of apoptotic cells appeared condensed and fragmented. Gadd $45 \beta$-silenced HuCCA- 1 cells exhibited an increased rate of apoptotic cells compared with negative control cells $(24.87 \pm 5.96 \%$ vs. $9.18 \pm 3.59 \%$; Fig. 3F-H). Consistently, western blot analysis revealed that poly (ADP-ribose) polymerase (PARP) cleavage and caspase-3 cleavage were observed, indicating that HuCCA-1 cells died via apoptosis when Gadd45 $\beta$ was silenced (Fig. 3I) (34).

Gadd $45 \beta$ silencing reduces Akt activity in HuCCA-1. To determine which signaling pathways were involved, three of the principal pathways involved in the regulation of cell viability and proliferation, the Akt, ERK and p38 MAPK pathways, were studied. Akt is associated with cell proliferation, survival and apoptosis inhibition (35). p38 MAPK is a stress-activated protein kinase pathway important for cell proliferation, differentiation, survival and migration (36,37). ERK1/2 activation has been demonstrated to protect cells from apoptosis (38).

Gadd $45 \beta$ silencing resulted in a marked reduction of Akt phosphorylation $(\mathrm{P}=0.0237)$, whereas no significant alteration in p38 MAPK or ERK1/2 phosphorylation was observed (Fig. 4A-D). The decrease in Akt activity may be responsible for the reduction of viability in HuCCA-1 upon Gadd $45 \beta$ silencing.

Gadd $45 \beta$ silencing reduces the invasion and migration of $H u C C A-1$ cells. A hallmark of malignancy is the ability to invade local tissues or to spread to distant sites (39). During this process, the cancer cells must acquire the ability to invade and migrate through connective tissue barriers, including the basement membrane, surrounding matrix and existing blood vessels (40). IHC data analysis of patient samples revealed that there was an association between the high expression of Gadd $45 \beta$ and metastasis (Table II). Furthermore, Gadd $45 \beta$ was demonstrated to be important for the viability of HuCCA-1 cells in the present study; viability is required by the cancer cells for successful metastasis (41). Therefore, the effect of Gadd $45 \beta$ silencing on the migration and invasion abilities of HuCCA-1 cells was investigated using in vitro transwell migration and invasion assays. Gadd $45 \beta$ silencing decreased
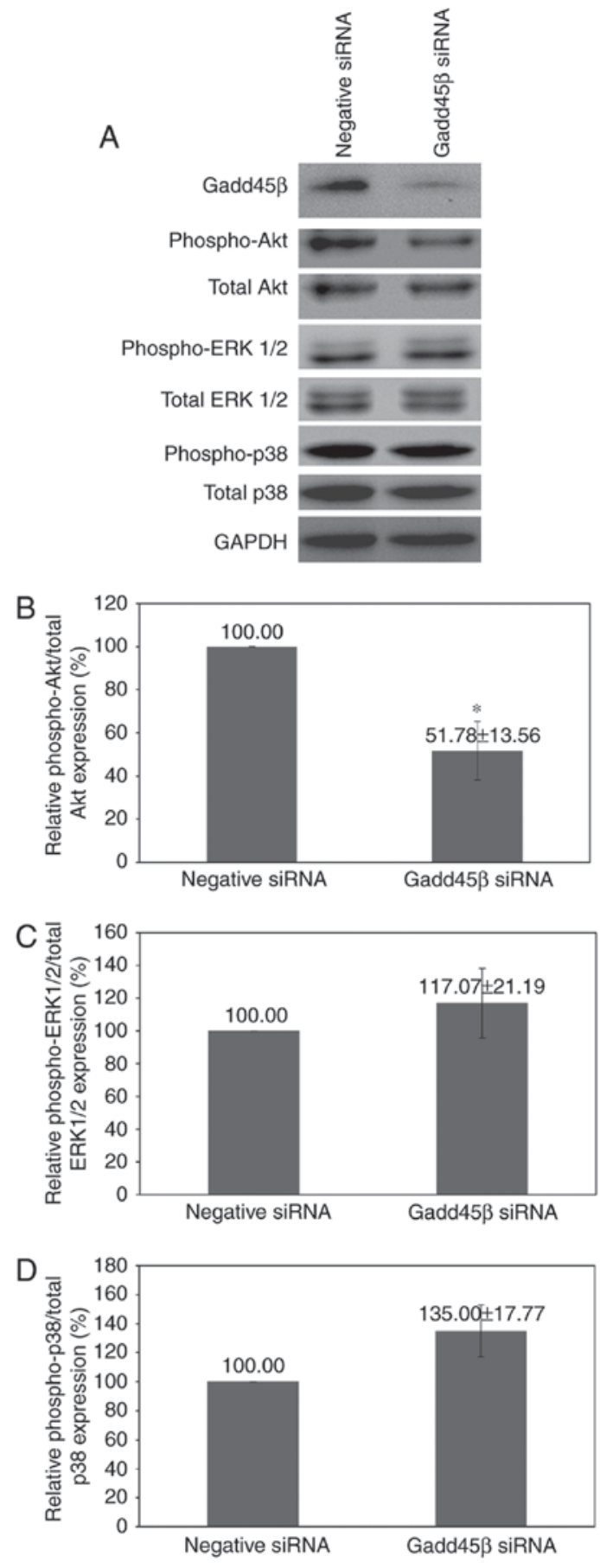

Figure 4. Effects of Gadd $45 \beta$ silencing upon major signaling pathways. (A) Representative images of the western blot analysis of p-Akt, p-p38 MAPK and p-ERK1/2 expression levels. Densitometry analysis for (B) p-Akt, (C) p-ERK1/2 and (D) p-p38 MAPK relative to the total form of each respective protein. Columns, mean of three independent experiments; bars, standard error of the mean; ${ }^{*} \mathrm{P}<0.05$. Gadd $45 \beta$, growth arrest and DNA damage-inducible- $\beta$; p38 MAPK, p38 mitogen-activated protein kinase; ERK, extracellular signal-regulated kinase.

the migration of HuCCA-1 cells to $35.67 \pm 5.60 \%$, and invasion to $39.59 \pm 11.09 \%$, compared with the negative control siRNA (Fig. 5A and B).

Cancer cells may secrete matrix metalloproteinases (MMPs) or stimulate surrounding stromal cells to secrete MMPs, consequently leading to digestion of the extracellular matrix, promoting local invasion and metastasis $(42,43)$. 
Table II. Association between Gadd45 $\beta$ expression and the clinicopathological features of patients with cholangiocarcinoma.

\begin{tabular}{|c|c|c|c|c|}
\hline \multirow[b]{2}{*}{ Clinicopathological parameter } & \multirow[b]{2}{*}{ Total } & \multicolumn{2}{|c|}{ Gadd $45 \beta$ expression } & \multirow[b]{2}{*}{ P-value } \\
\hline & & Low & High & \\
\hline Total, n (\%) & 28 & $7(25.0)$ & $21(75.0)$ & \\
\hline Age, years & & & & 0.378 \\
\hline Mean \pm standard deviation & $59.68 \pm 10.41$ & & & \\
\hline$<60, \mathrm{n}(\%)$ & $12(42.9)$ & $4(14.3)$ & $8(28.6)$ & \\
\hline$\geq 60, \mathrm{n}(\%)$ & $16(57.1)$ & $3(10.7)$ & $13(46.4)$ & \\
\hline Sex, n $(\%)$ & & & & 0.512 \\
\hline Male & $13(46.4)$ & $4(14.3)$ & $9(32.1)$ & \\
\hline Female & $15(53.6)$ & $3(10.7)$ & $12(42.9)$ & \\
\hline Tumor size, $\mathrm{cm}$ & & & & $0.385^{\mathrm{a}}$ \\
\hline Mean \pm standard deviation & $2.90 \pm 2.4$ & & & \\
\hline$<5, \mathrm{n}(\%)$ & $25(92.6)$ & $7(25.9)$ & $18(66.7)$ & \\
\hline$\geq 5, \mathrm{n}(\%)$ & $2(7.4)$ & $0(0)$ & $2(7.4)$ & \\
\hline Lymph node metastasis, n (\%) & & & & 0.190 \\
\hline Absent & $14(50.0)$ & $5(17.9)$ & $9(32.1)$ & \\
\hline Present & $14(50.0)$ & $2(7.1)$ & $12(42.9)$ & \\
\hline Distant metastasis, n (\%) & & & & $0.035^{\mathrm{c}}$ \\
\hline Absent & $19(67.9)$ & $7(25.0)$ & $12(42.9)$ & \\
\hline Present & $9(32.1)$ & $0(0)$ & $9(32.1)$ & \\
\hline Differentiation status, $\mathrm{n}(\%)$ & & & & $0.696^{\mathrm{b}}$ \\
\hline Well & $11(52.4)$ & $3(14.3)$ & $8(38.1)$ & \\
\hline Moderate & $10(47.6)$ & $2(9.5)$ & $8(38.1)$ & \\
\hline Type of surgery, n (\%) & & & & 0.076 \\
\hline R0 & $14(50.0)$ & $6(21.0)$ & $8(28.6)$ & \\
\hline R1 & $7(25.0)$ & $1(3.6)$ & $6(21.4)$ & \\
\hline $\mathrm{R} 2$ & $7(25.0)$ & $0(0)$ & $7(25.0)$ & \\
\hline
\end{tabular}

${ }^{\mathrm{a}}$ Tumor size data was not available in one case; ${ }^{\mathrm{b}}$ cell differentiation status data was not available in 7 cases; ${ }^{\mathrm{c}} \mathrm{P}<0.05$. Gadd $45 \beta$, growth arrest and DNA damage-inducible- $\beta$.

However, gelatin zymography analysis revealed that Gadd $45 \beta$ silencing did not significantly alter the activity of MMP-2 $(\mathrm{P}=0.5609)$ and MMP-9 $(\mathrm{P}=0.1886)$ secreted by HuCCA-1 cells (Fig. 5C-E).

Gadd $45 \beta$ silencing reverses the EMT changes in HuCCA-1. Epithelial-mesenchymal transition is an important process during cancer metastasis, denoted by acquisition of mesenchymal phenotypes, including increased motility and invasiveness (8,9,44-46). Since Gadd $45 \beta$ silencing decreased the invasion and migration of HuCCA-1 cells, properties associated with EMT, including morphological changes and EMT marker expression, were examined. It was demonstrated that Gadd $45 \beta$ silencing may have induced HuCCA-1 cells to undergo morphological changes, from spindle-shaped and fibroblast-like in appearance, to a flattened epithelial-like phenotype (Fig. 6A and B). The expression patterns of the proteins involved in the EMT pathway were further investigated with western blotting. It was identified that Gadd $45 \beta$ silencing affected the expression of multiple EMT markers (Fig. 7A-G). Epithelial marker E-cadherin expression was increased $(\mathrm{P}=0.0430)$, whereas the expression of the mesenchymal markers, Vimentin $(\mathrm{P}=0.0085)$ and Slug $(\mathrm{P}=0.0399)$, was decreased by Gadd $45 \beta$ silencing. However, there was no change in $\beta$-catenin expression ( $\mathrm{P}=0.6006$; Fig. 7A and $\mathrm{D})$.

Notably, proteins associated with tight junctions were also affected by Gadd $45 \beta$ silencing. Claudin- 1 and zona occludens protein 1 (ZO-1) constitute the tight junctions between cells $(47,48)$; one of the mechanisms involved in cancer invasion is collective migration, in which the expression levels of tight-junction proteins are important to allow cells to move as a cluster (49). There was a decrease in claudin-1 $(\mathrm{P}=0.0100$; Fig. 7A and F) and the ZO-1 expression ( $\mathrm{P}=0.0087$; Fig. 7A and $\mathrm{G}$ ) upon Gadd $45 \beta$ silencing.

\section{Discussion}

The IHC staining of paraffin embedded tissue samples from patients with CCA revealed that the majority of CCA tissue 

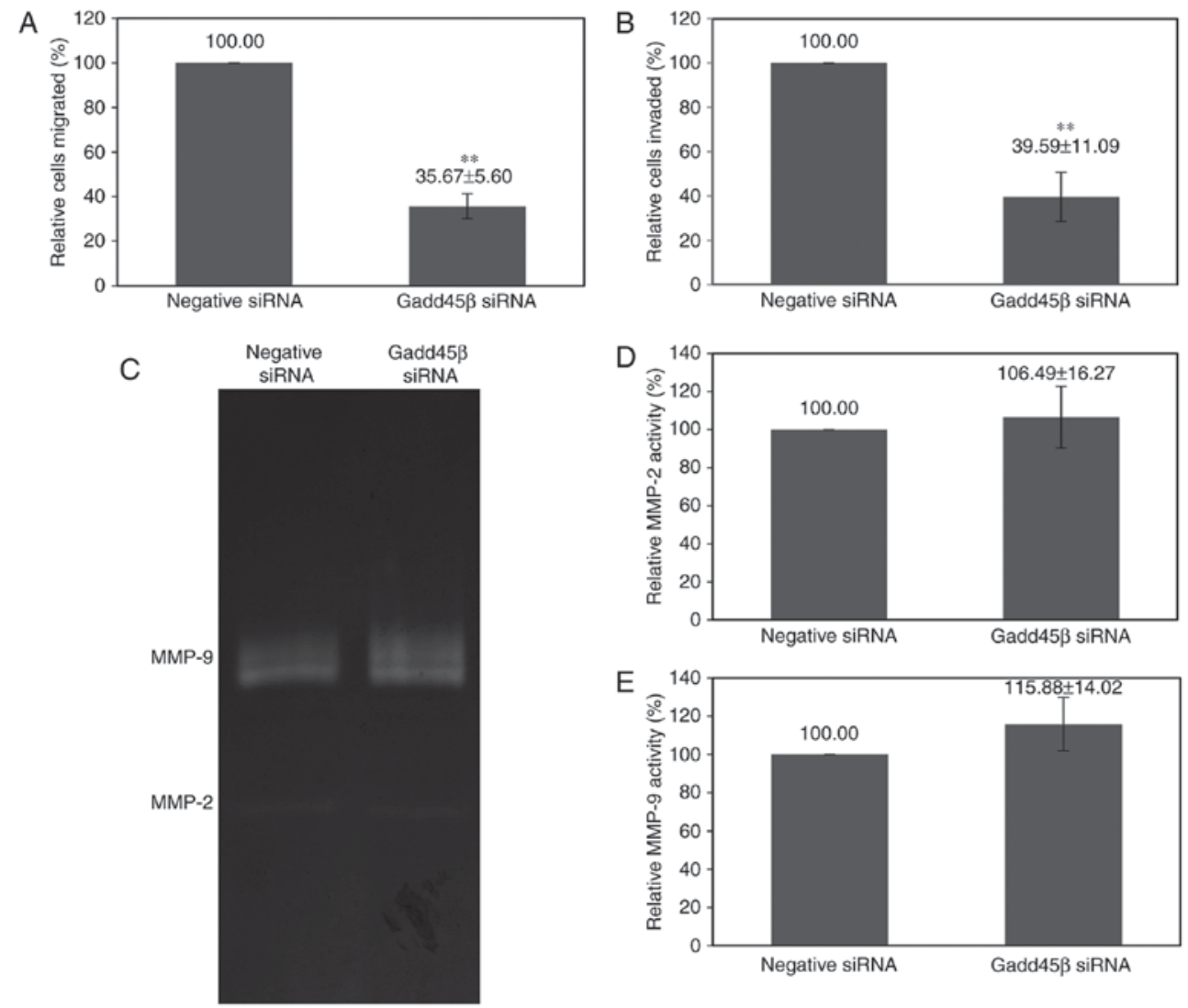

Figure 5. Gadd $45 \beta$ silencing decreased the in vitro migration and invasion of HuCCA-1, whereas MMP-2 and MMP-9 activity was not affected. Quantification of Transwell (A) migration and (B) invasion assays. The silencing of Gadd $45 \beta$ significantly decreased the in vitro invasion and migration activity of HuCCA-1 cells. (C) Gelatin zymography assay for secreted MMP-2 and -9. Densitometry analysis for (D) MMP-2 and (E) MMP-9. Columns, mean of three independent experiments; bars, standard deviation; " $\mathrm{P}<0.05 ;{ }^{* *} \mathrm{P}<0.01$. Gadd $45 \beta$, growth arrest and DNA damage-inducible- $\beta$; MMP, matrix metalloproteinase; siRNA, small interfering RNA.
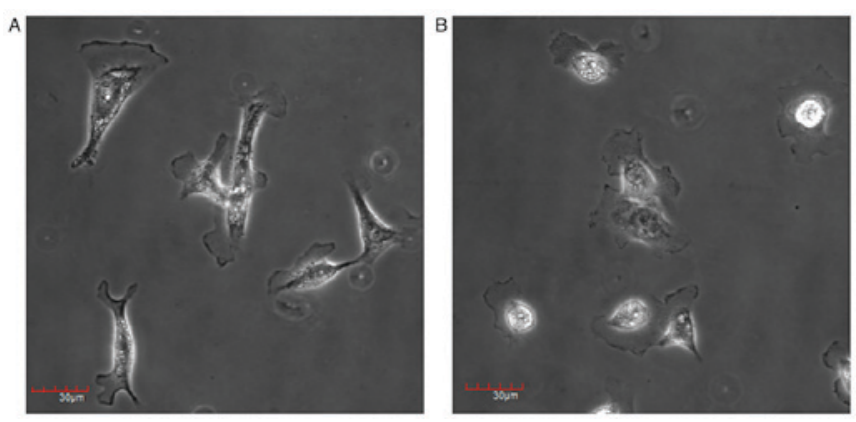

Figure 6. Effect of Gadd $45 \beta$ silencing upon cell morphology. Morphology of the HuCCA-1 cells at $48 \mathrm{~h}$ after (A) negative control siRNA and (B) Gadd $45 \beta$ siRNA transfection. HuCCA-1 cells changed in morphology from a spindle-shaped and fibroblast-like appearance to a flattened epithelial-like phenotype by Gadd $45 \beta$ silencing. Gadd $45 \beta$, growth arrest and DNA damage-inducible- $\beta$.

samples expressed increased Gadd $45 \beta$ relative to non-tumor tissue, and that the high level of Gadd $45 \beta$ in CCA was associated with an increased incidence of metastasis in patients. These findings suggest that Gadd $45 \beta$ may be of functional importance in CCA. As cancer cells are continuously exposed to stressful environments including hypoxia, competition for nutrients and oxidative stress during growth (23), Gadd $45 \beta$ appears to enable CCA cells to cope with stress and to thrive in the harsh tumor microenvironment.
In the present study, the functional importance of Gadd $45 \beta$ in CCA was determined using siRNA-mediated gene silencing in HuCCA-1, a cell line established from a patient with CCA. Gadd $45 \beta$ silencing decreased the proliferation and induced apoptosis in HuCCA-1 cells, as demonstrated by nuclear condensation and fragmentation, together with the activation of caspase-3 and PARP cleavage. The impairment of cell proliferation together with an increased rate of apoptosis in Gadd $45 \beta$-silenced cells suggests that Gadd $45 \beta$ serves a pro-survival role in CCA. These data are in agreement with previous reports on genotoxic stress-induced apoptosis in hematopoietic cells of Gadd45 $\beta$-deficient mice (50). Additionally, Gadd $45 \beta$ has been demonstrated to promote the survival of mouse embryo fibroblasts in response to tumor necrosis factor- $\alpha$ (51) and of B cells during Fas-induced apoptosis (52).

To study the underlying molecular mechanisms by which Gadd $45 \beta$ promotes viability in HuCCA-1, key cellular survival and death signaling pathways were studied, since the activation of death signals or the reduction of survival signals reduces the viability of cells. The results of the present study demonstrated that Gadd $45 \beta$ silencing significantly decreased the Akt activity, although p38 MAPK and ERK1/2 activity was unchanged. Activation of the Akt/PI3K pathway has been associated with growth and metastasis (53); therefore, the decrease in p-Akt may be responsible for the reduced growth 

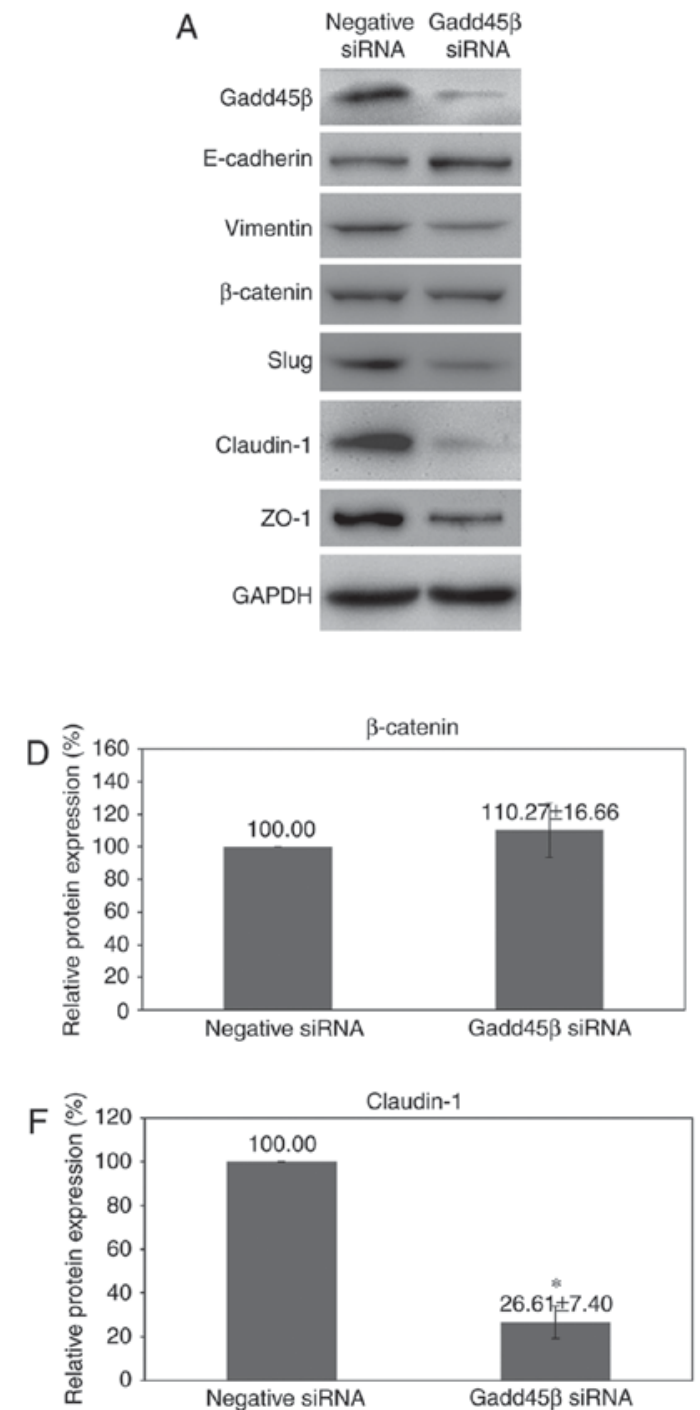
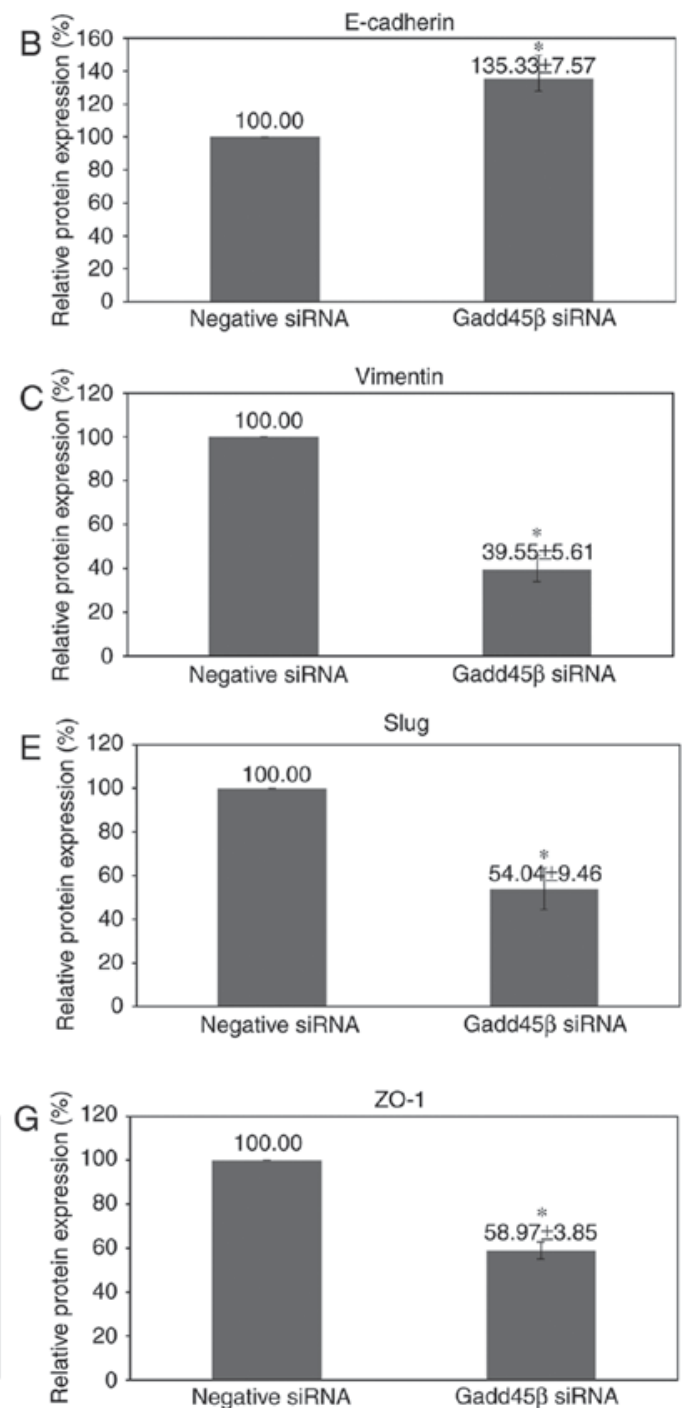

Figure 7. Effect of Gadd45 $\beta$ silencing upon EMT marker expression. (A) Representative images of western blot analysis for the expression of E-cadherin, vimentin, $\beta$-catenin, Slug, claudin-1 and ZO-1 at $48 \mathrm{~h}$ after Gadd45 $\beta$ silencing in HuCCA-1. Densitometry analysis of (B) E-cadherin, (C) vimentin, (D) $\beta$-catenin, (E) Slug, (F) claudin-1 and (G) ZO-1. Columns, mean of three independent experiments; bars, standard error of the mean. * $<<0.05$. Gadd $45 \beta$, growth arrest and DNA damage-inducible- $\beta$; EMT, epithelial-mesenchymal transition; ZO-1, zona occludens protein 1 ; siRNA, small interfering RNA.

and induction of apoptosis in HuCCA- 1 cells upon Gadd4 $5 \beta$ silencing. The altered cell signaling activities appeared to shift the balance from pro-survival to pro-apoptotic following the silencing of Gadd45 $\beta$.

EMT is an important biological process that allows malignant tumor cells to acquire migratory and invasive phenotypes; prerequisites for cancer invasion and metastasis. It is indicated by the acquisition of fibroblast-like morphology, with a reduction in intercellular adhesion and increased cell motility (11-18). The IHC data from the present study indicated that Gadd $45 \beta$ may be involved in the metastasis of CCA. Gadd $45 \beta$ silencing of HuCCA-1 cells induced a marked reduction in invasiveness and migration, although the activity of MMPs was not affected. A number of reports have implicated Gadd $45 \beta$ in the cell migration ability, an important characteristic of metastatic cancer cells. For example Salerno et al (54) demonstrated that the granulocytes of Gadd $45 \beta$-deficient mice displayed the impairment of lipopolysacchiride-stimulated chemotactic migration. Furthermore, Kodama and Negishi (55) demonstrated that the ectopic expression of Gadd $45 \beta$ increased, whereas siRNA-mediated silencing of Gadd $45 \beta$ decreased, pregnane $\mathrm{X}$ receptor-induced cell migration in hepatocellular carcinoma cells.

Examination of the expression of EMT markers revealed that Gadd $45 \beta$ silencing resulted in reduction in Slug expression, with a consequent increase in E-cadherin and decrease in vimentin expression. High Slug expression has been demonstrated to induce EMT in cancer cells (56) and the effects are orchestrated by an increase in vimentin expression (57). As Slug expression is negatively regulated by GS3K $\beta$ (58), which in turn is inactivated by pAkt (59), the decrease in Akt activity following Gadd $45 \beta$ silencing may have led to the downregulation of Slug expression, with the consequent suppression of vimentin expression and an increase in the invasiveness and migration of HuCCA-1 cells.

Furthermore, a decrease in the expression of the tight junction proteins, claudin-1 and ZO-1, was induced by Gadd $45 \beta$ silencing. Claudins and ZO-1 are integral proteins of the tight junctions that seal adjacent epithelial cells $(47,48)$. Although the conventional roles of claudins and ZO-1 are to 
control paracellular ion flux and maintain cell polarity, accumulating evidence has demonstrated that these proteins also exhibit non-junctional functions, including in cell motility, and may function in the EMT, apoptosis resistance, invasion and metastasis of cancer cells (60-62). Claudins have been demonstrated to promote collective migration, where groups of cells move in a coordinated manner and remain connected via cell-cell junctions. Additionally, claudin expression has been associated with increased MMP activity and cell survival (62). Claudin-1 expression has been demonstrated to be associated with invasive and metastatic phenotypes in a range of types of cancer including colon, liver, oral squamous cell carcinoma and melanoma (63). ZO-1 is a component of the 'junctional plaque' at the cytoplasmic surface of the tight junctions, which links integral membrane proteins with the cytoskeleton (64). It was identified in a previous study that ZO-1 can translocate from the cell membrane to the nucleus and may be involved in cell signaling (65). The upregulation of ZO-1 has been reported in melanoma, and the silencing of ZO-1 led to a marked reduction in the rate of cell invasion (66). Thus, the identified association between a decrease in claudin-1 and ZO-1 expression with impaired cell invasion and migration in the present study appears to be consistent with these studies.

In conclusion, the silencing of Gadd $45 \beta$ significantly decreased the viability, metastatic phenotypes and EMT markers of HuCCA- 1 cells, suggesting that Gadd $45 \beta$ serves a function in the metastatic process in CCA. This is in accord with the IHC data of patients with CCA, in which Gadd $45 \beta$ expression was associated with metastasis. However, a limitation of this study was that the experiments were performed in only one CCA cell line. Further studies should be performed in more CCA cell lines with more stable knock down systems, as transient siRNA transfection has a limited gene silencing duration. The study of Gadd $45 \beta$ expression, function and Gadd $45 \beta$-mediated signaling pathways in CCA will be important in understanding cancer biology, in which the cancer cells are dynamically evolving with accumulated mutations. Since the cancer cells must thrive in a competitive environment, a stress response protein like Gadd $45 \beta$ may be critical. The understanding or manipulation of Gadd $45 \beta$-dependent survival signaling and EMT pathways may be beneficial as a potential therapeutic option, adjuvant to the conventional therapies for CCA.

\section{Acknowledgements}

The authors thank Professor Satitaya Sirisinha (Mahidol University, Bangkok, Thailand) for providing the HuCCA-1 cell line and the Central Instrument Facility, Center of Nanoimaging, Faculty of Science of Mahidol University. The authors express their thanks to Professor Tavan Janvilisri and Ms. Phorutai Pearngam for assistance in the study of EMT pathways. The present study was supported by Mahidol University (grant no. 18/2555).

\section{References}

1. Blechacz B and Gores GJ: Cholangiocarcinoma: Advances in pathogenesis, diagnosis, and treatment. Hepatology 48: 308-321, 2008 .
2. Welzel TM, McGlynn KA, Hsing AW, O'Brien TR and Pfeiffer RM: Impact of classification of hilar cholangiocarcinomas (Klatskin tumors) on the incidence of intra- and extrahepatic cholangiocarcinoma in the United States. J Natl Cancer Inst 98: 873-875, 2006.

3. Farley DR, Weaver AL and Nagorney DM: 'Natural history' of unresected cholangiocarcinoma: Patient outcome after noncurative intervention. Mayo Clin Proc 70: 425-429, 1995.

4. Anderson CD, Pinson CW, Berlin J and Chari RS: Diagnosis and treatment of cholangiocarcinoma. Oncologist 9: 43-57, 2004.

5. Sripa B, Brindley PJ, Mulvenna J, Laha T, Smout MJ, Mairiang E, Bethony JM and Loukas A: The tumorigenic liver fluke Opisthorchis viverrini-multiple pathways to cancer. Trends Parasitol 28: 395-407, 2012.

6. Sripa B, Kaewkes S, Sithithaworn P, Mairiang E, Laha T, Smout M, Pairojkul C, Bhudhisawasdi V, Tesana S, Thinkamrop B, et al: Liver fluke induces cholangiocarcinoma. PLoS Med 4: e201, 2007.

7. Weigelt B, Peterse JL and van't Veer LJ: Breast cancer metastasis: Markers and models. Nat Rev Cancer 5: 591-602, 2005.

8. Heerboth S, Housman G, Leary M, Longacre M, Byler S, Lapinska K, Willbanks A and Sarkar S: EMT and tumor metastasis. Clin Transl Med 4: 6, 2015.

9. Nieto MA: Epithelial plasticity: A common theme in embryonic and cancer cells. Science 342: 1234850, 2013.

10. Moreno-Bueno G, Portillo F and Cano A: Transcriptional regulation of cell polarity in EMT and cancer. Oncogene 27: 6958-6969, 2008.

11. Peinado H, Olmeda D and Cano A: Snail, Zeb and bHLH factors in tumour progression: An alliance against the epithelial phenotype? Nat Rev Cancer 7: 415-428, 2007.

12. Adhikary A, Chakraborty S, Mazumdar M, Ghosh S, Mukherjee S, Manna A, Mohanty S, Nakka KK, Joshi S, De A, et al: Inhibition of epithelial to mesenchymal transition by E-cadherin up-regulation via repression of slug transcription and inhibition of E-cadherin degradation: Dual role of scaffold/matrix attachment region-binding protein 1 (SMAR1) in breast cancer cells. J Biol Chem 289: 25431-25444, 2014.

13. Techasen A, Loilome W, Namwat N, Khuntikeo N, Puapairoj A, Jearanaikoon P, Saya $\mathrm{H}$ and Yongvanit P: Loss of E-cadherin promotes migration and invasion of cholangiocarcinoma cells and serves as a potential marker of metastasis. Tumour Biol 35: 8645-8652, 2014.

14. Mendez MG, Kojima S and Goldman RD: Vimentin induces changes in cell shape, motility, and adhesion during the epithelial to mesenchymal transition. FASEB J 24: 1838-1851, 2010.

15. Chaw SY, Majeed AA, Dalley AJ, Chan A, Stein S and Farah CS: Epithelial to mesenchymal transition (EMT) biomarkers-E-cadherin, beta-catenin, APC and Vimentin-in oral squamous cell carcinogenesis and transformation. Oral Oncol 48: 997-1006, 2012.

16. Qiu W, David D, Zhou B, Chu PG, Zhang B, Wu M, Xiao J, Han T, Zhu Z, Wang T, et al: Down-regulation of growth arrest DNA damage-inducible gene 45beta expression is associated with human hepatocellular carcinoma. Am J Pathol 162: 1961-1974, 2003.

17. Zumbrun SD, Hoffman B and Liebermann DA: Distinct mechanisms are utilized to induce stress sensor gadd $45 \mathrm{~b}$ by different stress stimuli. J Cell Biochem 108: 1220-1231, 2009.

18. Liebermann DA and Hoffman B: Gadd45 in stress signaling. J Mol Signal 3: 15, 2008.

19. Vairapandi M, Balliet AG, Fornace AJ Jr, Hoffman B and Liebermann DA: The differentiation primary response gene MyD118, related to GADD45, encodes for a nuclear protein which interacts with PCNA and p21WAF1/CIP1. Oncogene 12: 2579-2594, 1996

20. Smith ML, Ford JM, Hollander MC, Bortnick RA, Amundson SA, Seo YR, Deng CX, Hanawalt PC and Fornace AJ Jr: p53-mediated DNA repair responses to UV radiation: Studies of mouse cells lacking p53, p21, and/or gadd45 genes. Mol Cell Biol 20: 3705-3714, 2000.

21. Jónsson ZO and Hübscher U: Proliferating cell nuclear antigen: More than a clamp for DNA polymerases. Bioessays 19: 967-975, 1997.

22. Kelman Z and Hurwitz J: Protein-PCNA interactions: A DNA-scanning mechanism? Trends Biochem Sci 23: 236-238, 1998.

23. Leprivier G, Rotblat B, Khan D, Jan E and Sorensen PH: Stress-mediated translational control in cancer cells. Biochim Biophys Acta 1849: 845-860, 2015. 
24. Qiu W, Zhou B, Zou H, Liu X, Chu PG, Lopez R, Shih J, Chung $\mathrm{C}$ and Yen Y: Hypermethylation of growth arrest DNA damage-inducible gene 45 beta promoter in human hepatocellular carcinoma. Am J Pathol 165: 1689-1699, 2004.

25. Wang L, Xiao X, Li D, Chi Y, Wei P, Wang Y, Ni S, Tan C, Zhou X and Du X: Abnormal expression of GADD45B in human colorectal carcinoma. J Transl Med 10: 215, 2012.

26. Meir T, Dror R, Yu X, Qian J, Simon I, Pe'er J and Chowers I: Molecular characteristics of liver metastases from uveal melanoma. Invest Ophthalmol Vis Sci 48: 4890-4896, 2007.

27. Inowa $\mathrm{T}$, Hishikawa $\mathrm{K}$, Matsuzaki $\mathrm{Y}$, Isagawa $\mathrm{T}$, Takeuchi $\mathrm{T}$, Aburatani H, Kitamura T and Fujita T: GADD45 $\beta$ determines chemoresistance and invasive growth of side population cells of human embryonic carcinoma. Stem Cells Int 2010: 782967 2010.

28. Sirisinha S, Tengchaisri T, Boonpucknavig S, Prempracha N, Ratanarapee S and Pausawasdi A: Establishment and characterization of a cholangiocarcinoma cell line from a Thai patient with intrahepatic bile duct cancer. Asian Pac J Allergy Immunol 9: 153-157, 1991.

29. Pongcharoen P, Jinawath A and Tohtong R: Silencing of CD44 by siRNA suppressed invasion, migration and adhesion to matrix, but not secretion of MMPs, of cholangiocarcinoma cells. Clin Exp Metastasis 28: 827-839, 2011

30. Schneider CA, Rasband WS and Eliceiri KW: NIH Image to ImageJ: 25 years of image analysis. Nat Methods 9: 671-675, 2012.

31. Li YH and Zhu C: A modified Boyden chamber assay for tumor cell transendothelial migration in vitro. Clin Exp Metastasis 17: 423-429, 1999.

32. Uhlen M, Fagerberg L, Hallström BM, Lindskog C Oksvold P, Mardinoglu A, Sivertsson Å, Kampf C, Sjöstedt E, Asplund A, et al: Proteomics. Tissue-based map of the human proteome. Science 347: 1260419, 2015.

33. Kerr JF, Wyllie AH and Currie AR: Apoptosis: A basic biological phenomenon with wide-ranging implications in tissue kinetics. Br J Cancer 26: 239-257, 1972.

34. Tewari M, Quan LT, O'Rourke K, Desnoyers S, Zeng Z, Beidler DR, Poirier GG, Salvesen GS and Dixit VM: Yama/CPP32 beta, a mammalian homolog of CED-3, is a CrmA-inhibitable protease that cleaves the death substrate poly(ADP-ribose) polymerase. Cell 81: 801-809, 1995.

35. Kumar A, Rajendran V, Sethumadhavan R and Purohit R: Akt kinase pathway: A leading target in cancer research. ScientificWorld Journal 2013: 756134, 2013

36. Nebreda AR and Porras A: p38 MAP kinases: Beyond the stress response. Trends Biochem Sci 25: 257-260, 2000.

37. Kyriakis JM and Avruch J: Mammalian mitogen-activated protein kinase signal transduction pathways activated by stress and inflammation. Physiol Rev 81: 807-869, 2001.

38. Erhardt P, Schremser EJ and Cooper GM: B-Raf inhibits programmed cell death downstream of cytochrome c release from mitochondria by activating the MEK/Erk pathway. Mol Cell Biol 19: 5308-5315, 1999.

39. Hanahan D and Weinberg RA: Hallmarks of cancer: The next generation. Cell 144: 646-674, 2011.

40. Talmadge JE and Fidler IJ: AACR centennial series: The biology of cancer metastasis: Historical perspective. Cancer Res 70 5649-5669, 2010

41. Mehlen P and Puisieux A: Metastasis: A question of life or death Nat Rev Cancer 6: 449-458, 2006.

42. Davies KJ: The complex interaction of matrix metalloproteinases in the migration of cancer cells through breast tissue Stroma. Int J Breast Cancer 2014: 839094, 2014.

43. Roomi MW, Monterrey JC, Kalinovsky T, Rath M and Niedzwiecki A: Patterns of MMP-2 and MMP-9 expression in human cancer cell lines. Oncol Rep 21: 1323-1333, 2009.

44. Micalizzi DS, Farabaugh SM and Ford HL: Epithelial-mesenchymal transition in cancer: Parallels between norma development and tumor progression. J Mammary Gland Biol Neoplasia 15: 117-134, 2010

45. Powell DR, Blasky AJ, Britt SG and Artinger KB: Riding the crest of the wave: Parallels between the neural crest and cancer in epithelial-to-mesenchymal transition and migration. Wiley Interdiscip Rev Syst Biol Med 5: 511-522, 2013.

46. Wallerand H, Cai Y, Wainberg ZA, Garraway I, Lascombe I, Nicolle G, Thiery JP, Bittard H, Radvanyi F and Reiter RR Phospho-Akt pathway activation and inhibition depends on $\mathrm{N}$-cadherin or phospho-EGFR expression in invasive human bladder cancer cell lines. Urol Oncol 28: 180-188, 2010.
47. Furuse M, Fujita K, Hiiragi T, Fujimoto K and Tsukita S: Claudin-1 and -2: Novel integral membrane proteins localizing at tight junctions with no sequence similarity to occludin. J Cell Biol 141: 1539-1550, 1998

48. Stevenson BR, Siliciano JD, Mooseker MS and Goodenough DA: Identification of ZO-1: A high molecular weight polypeptide associated with the tight junction (zonula occludens) in a variety of epithelia. J Cell Biol 103: 755-766, 1986.

49. Rørth P: Collective cell migration. Annu Rev Cell Dev Biol 25: 407-429, 2009

50. Gupta M, Gupta SK, Balliet AG, Hollander MC, Fornace AJ, Hoffman B and Liebermann DA: Hematopoietic cells from Gadd45a- and Gadd45b-deficient mice are sensitized to genotoxic-stress-induced apoptosis. Oncogene 24: 7170-7179, 2005.

51. De Smaele E, Zazzeroni F, Papa S, Nguyen DU, Jin R, Jones J, Cong R and Franzoso G: Induction of gadd45beta by NF-kappaB downregulates pro-apoptotic JNK signalling. Nature 414: 308-313, 2001.

52. Zazzeroni F, Papa S, Algeciras-Schimnich A, Alvarez K, Melis T, Bubici C, Majewski N, Hay N, De Smaele E,Peter ME and Franzoso G: Gadd45 beta mediates the protective effects of CD40 costimulation against Fas-induced apoptosis. Blood 102: 3270-3279, 2003.

53. Yothaisong S, Dokduang $H$, Techasen A, Namwat N, Yongvanit $P$, Bhudhisawasdi V, Puapairoj A, Riggins GJ and Loilome W: Increased activation of PI3K/Akt signaling pathway is associated with cholangiocarcinoma metastasis and PI3K/mTOR inhibition presents a possible therapeutic strategy. Tumour Biol 34 3637-3648, 2013

54. Salerno DM, Tront JS, Hoffman B and Liebermann DA: Gadd45a and Gadd45b modulate innate immune functions of granulocytes and macrophages by differential regulation of p38 and JNK signaling. J Cell Physiol 227: 3613-3620, 2012.

55. Kodama $S$ and Negishi M: Pregnane $X$ receptor PXR activates the GADD45beta gene, eliciting the p38 MAPK signal and cell migration. J Biol Chem 286: 3570-3578, 2011.

56. Medici D, Hay ED and Olsen BR: Snail and Slug promote epithelial-mesenchymal transition through beta-catenin-T-cell factor-4-dependent expression of transforming growth factor-beta3. Mol Biol Cell 19: 4875-4887, 2008

57. Vuoriluoto K, Haugen H, Kiviluoto S, Mpindi JP, Nevo J, Gjerdrum C, Tiron C, Lorens JB and Ivaska J: Vimentin regulates EMT induction by Slug and oncogenic $\mathrm{H}$-Ras and migration by governing Axl expression in breast cancer. Oncogene 30 : 1436-1448, 2011

58. Kim JY, Kim YM, Yang $\mathrm{CH}$, Cho SK, Lee JW and Cho M Functional regulation of Slug/Snail2 is dependent on GSK-3 $\beta$-mediated phosphorylation. FEBS J 279: 2929-2939, 2012.

59. Cross DA, Alessi DR, Vandenheede JR, McDowell HE, Hundal HS and Cohen P: The inhibition of glycogen synthase kinase- 3 by insulin or insulin-like growth factor 1 in the rat skeletal muscle cell line L6 is blocked by wortmannin, but not by rapamycin: Evidence that wortmannin blocks activation of the mitogen-activated protein kinase pathway in L6 cells between Ras and Raf. Biochem J 303: 21-26, 1994.

60. Bezdekova M, Brychtova S, Sedlakova E, Langova K, Brychta T and Belej K: Analysis of Snail-1, E-cadherin and claudin-1 expression in colorectal adenomas and carcinomas. Int J Mol Sci 13: 1632-1643, 2012

61. Stebbing J, Filipovic A and Giamas G: Claudin-1 as a promoter of EMT in hepatocellular carcinoma. Oncogene 32: 4871-4872, 2013

62. Oliveira SS and Morgado-Diaz JA: Claudins: Multifunctional players in epithelial tight junctions and their role in cancer. Cell Mol Life Sci 64: 17-28, 2007.

63. Kwon MJ: Emerging roles of claudins in human cancer. Int J Mol Sci 14: 18148-18180, 2013.

64. BauerH,Zweimueller-Mayer J, Steinbacher P,Lametschwandtner A and Bauer HC: The dual role of zonula occludens $(\mathrm{ZO})$ proteins. J Biomed Biotechnol 2010: 402593, 2010.

65. Gottardi CJ, Arpin M, Fanning AS and Louvard D: The junction-associated protein, zonula occludens-1, localizes to the nucleus before the maturation and during the remodeling of cell-cell contacts. Proc Natl Acad Sci USA 93: 10779-10784, 1996.

66. Smalley KS, Brafford P, Haass NK, Brandner JM, Brown E and Herlyn M: Up-regulated expression of zonula occludens protein-1 in human melanoma associates with N-cadherin and contributes to invasion and adhesion. Am J Pathol 166: 1541-1554, 2005.

This work is licensed under a Creative Commons Attribution-NonCommercial-NoDerivatives 4.0 International (CC BY-NC-ND 4.0) License. 